\title{
Improvement of Murrah Buffalo Milk Production Fed Palm Oil Solid Waste Containing Ration
}

\author{
P. Mahyuddin \\ Indonesia Research Institue for Animal Production \\ Jln. Veteran III PO. Box 221 Ciawi - Bogor 16002, Indonesia \\ (Received 16-10-2009; accepted 29-06-2010)
}

\begin{abstract}
A field trial was conducted to study the effect of dietary inclusion of palm oil solid waste on milk production of murrah buffalo raised under palm oil plantation. Two farms from different districts were involved in this study. Forty cows with 7-9 month pregnancy were selected from each farm and they were divided into control and treatment groups. Cows in control group were offered a mixed supplement of $1 \mathrm{~kg}$ copra meal $+2 \mathrm{~kg}$ fresh grated cassava root + mineral mix and treatments group were offered the control diet $+1 \mathrm{~kg}$ palm oil solid waste. The dietary supplement was offered to the cows for 2 months before and 2 months period after calving. The cows were grazed under palm oil plantation. The addition of palm oil solid waste in the diet improved $(P<0.05)$ milk yield $(8.51 / \mathrm{d}$ vs $10.51 / \mathrm{d})$, calves weight at birth $(19.6 \mathrm{~kg}$ vs $22.1 \mathrm{~kg})$ and live weight gain of the calves $(0.66 \mathrm{~kg} / \mathrm{d} \mathrm{vs} 0.99$ $\mathrm{kg} / \mathrm{d}$ ). Additional dietary inclusion of palm oil solid waste improved milk yield of murrah buffalo, and further improvement of milk yield was expected to achieve by higher inclusion of palm oil solid waste in the diet.
\end{abstract}

Key words: palm oil waste, murrah buffalo, milk yield

\section{INTRODUCTION}

Indonesia is estimated to have 6 million ha of palm oil plantation, an enormous potential for the development of large ruminants. The cover crops particularly under 5 years old palm oil which consist of grasses and pasture legumes are good source of forage. The palm oil industry generates by-products such as palm kernel cake (PKC), palm press fiber (PPF) and sludge cake or decanter cake (solid waste) which can be used as feedstuff. Palm kernel cake is known to have high nutritive value (Yatno et al., 2008) compared to other palm oil by-products and has been used as an ingredient in concentrate feed. In Indonesia, PKC is mostly exported to overseas, only solid waste that left untouched by the plantation owner, yet it is potential to be used as a feed. There are only few farmers who live around the palm oil factory use this by-product as supplement for their livestock. The farmers is lack of knowledge on nutritive value of the by-product and most farmers live too far away from the factory so need cost to transport it. Solid waste contains $1.5 \%$ oil and $25 \%$ water, it easily get rancid and contaminated by fungus (Utomo \& Wijaya,

* Corresponding author:

Indonesia Research Institue for Animal Production

Jln. Veteran III PO. Box 221 Ciawi - Bogor 16002, Indonesia

e-mail: pmahyuddin@yahoo.com
2004). Therefore, it has to be offered fresh, or anaerobicly stored or dried milled.

The production of palm oil solid waste is approximately 2\%-3\% (Utomo \& Wijaya, 2004) of empty fruit bunch. It depends on the capacity, facility of the factory and EFB produced. A palm oil factory can produce solid waste of approximately 8-20 ton/day. Indonesia is estimated to produce palm oil solid waste as much as 460.000 ton/year (BPS, 2002). This solid waste is only produced by a palm oil factory which has facilities of 3 phases (decanter) that can separate sludge from the solid part.

There have been some studies on the use of palm oil solid waste as feed for cattle, sheep and goat, duck, and chicken. Utomo \& Widjaja (2004) reported that dietary supplementation of palm oil solid waste at $1.5 \%$ of body weight (BW) and ad libitum resulted in live weight gain (LWG) of $0.45 \mathrm{~kg} / \mathrm{d}$ and $0.77 \mathrm{~kg} / \mathrm{d}$ compared to control $(0.06 \mathrm{~kg} / \mathrm{d})$ in cattle. Further more, dietary supplementation of palm oil solid waste at $1 \%$ BW resulted in LWG of $0.05 \mathrm{~kg} / \mathrm{d}$ in sheep (Utomo \& Widjaja, 2004). While in another study, sheep offered $21 \%$ of palm oil solid waste in their concentrate diet showed a LWG of 132.2 g/d (Batubara, 2003). When palm oil solid waste was fermented, $0.07 \mathrm{~kg} / \mathrm{d}$ of LWG could be reached in both sheep and goat (Utomo \& Widjaja, 2004). The increased LWG in animal offered fermented palm oil solid waste was caused by increased in metabolizable energy (ME) compared to the unfermented one. Increased ME in 
fermented palm oil solid waste was due to a reduction in fiber and an increase in protein content (Pasaribu et al., 1998). The cost of fermentation however, needs to be considered economically.

The report on the utilization of palm oil solid waste in buffalo, particularly dairy buffalo (murrah) is not available. Although milk production potential of dairy buffalo may not reach that of Holstein Friesian, its chemical composition is superior for human health. Buffalo milk has $37 \%$ more Ca, $14 \%$ more protein, $45 \%$ more fat but $80 \%$ less cholesterol, 37\% more Ca, $20 \%$ more P than cow milk (Chantalakkana \& Falvey, 1999). Furthermore, since buffalo milk has lower water content and higher fat content, it is more viable to manufacture the fat-based and SNF-based milk products such as butter, ghee, cheese and milk powder, therefore it is sold for better price in South Asia (Sarwar et al., 2002).

In Indonesia, producing milk of Murrah buffaloes is a source of income. Most of buffalo farmers are reared around palm oil plantation in North Sumatera by Indian ethnics. Milk yield may range from $2 \mathrm{l} / \mathrm{d}$ to $6 \mathrm{l} / \mathrm{d}$. The farmers however, have not used palm oil solid waste as supplement. This paper reports a field study on the use of palm oil solid waste to improve milk production of murrah buffalo.

\section{MATERIALS AND METHODS}

Eighty (80) buffalo cows (4 years old) with 7-9 month pregnancy and estimated body weight (BW) of $500 \mathrm{~kg}$ were randomly chosen from 2 farmers at Deli Serdang district in North Sumatera. Dalton tape was used to estimate body weight of the cows. The cows were raised under the existing farm management system, whereby all cows were grazed under palm oil plantation and fed supplement containing $1 \mathrm{~kg}$ coconut meal and $2 \mathrm{~kg}$ fresh grated cassava root (cassava meal). Forty cows in each farm were divided into control and dietary treatment groups. The control diet consisted of $1 \mathrm{~kg}$ coconut meal $+2 \mathrm{~kg}$ cassava meal (50\% moisture) + mineral mix. The dietary treatment consisted of the control diet $+1 \mathrm{~kg}$ dried milled palm oil solid waste. These ingredients were mixed thoroughly and offered twice a day in the barn during milking before the cows were grazed under palm oil plantation. This feeding trial was carried out for 2 months before and 2 months after calving.

The cows were hand milked twice daily at 04.30 am and $04.30 \mathrm{pm}$. Daily milk yield of each cow was recorded using graduated cylinder for the first 2 months of lactation. Body weight of calves was measured at calving and 2 months afterward, using battery operated weighing scale.

The forage consumption was not measured since animals were grazed under oilpalm plantation twice a day after each milking. However, the total dry matter intake was estimated using MAFF (1975) equation for dairy cows of $\mathrm{DMI}=0.025 \mathrm{LW}+0.1 \mathrm{Y}$. $\mathrm{LW}$ is live weight and $Y$ is milk yield $(\mathrm{kg} / \mathrm{d})$. Since the supplement was all eaten, the dry matter intake of forage is calculated by difference between total dry matter intake and supplement intake.
Proximate analysis was conducted on coconut meal, grated cassava and palm oil solid waste according to AOAC (1984). To estimate ME, in vitro organic matter digestibility (IVOMD) was carried out using Tilley and Terry (1963) method. The ME was estimated based on MAFF (1975) according to the equation of $\mathrm{ME}=0.15 \mathrm{x}$ IVOMD.

\section{RESULTS AND DISCUSSION}

\section{Nutritive Value of Forage and the Supplement}

The cover crops under palm oil plantation consist of various tropical grasses and legumes. Some of the grasses noticed were naturally growing grasses such as Imperata cylindrica, Ottochloa nodosa, Paspalum conjugatum, Clidemia sp, Asystasia sp, Mikania sp; while most of the legumes were introduced such as, Calopogonium mucunoides, Centrosema pubescens, and Pueraria javanica.

Forage is required by ruminants not only as a source of fiber but also as a source of vitamins and minerals. The protein and ME content of cover crops under palm oil plantation ranged $8 \%-17 \%$ and $7-10 \mathrm{MJ} / \mathrm{kg}$ respectively (Table 1). In general large ruminants can grow approximately $0.25 \mathrm{~kg} / \mathrm{d}$ when grazed under palm oil plantation. Although buffaloes have been found to have a better degradation of both protein and protein-free dry matter (Terramoccia et al., 2000) which is possibly caused by a greater number of microbial population (Wanapat et al., 2000; Wanapat et al., 2003; Puppo et al., 2002) than cattle, feeding forage as a sole diet for lactating buffaloes may not meet their nutrient requirements. Metabolizable energy is thought to limit milk production from foragebased diet (Kolver, 2003). The farmers involved in this study have been using coconut meal and cassava meal as feed supplement for dairy buffalo. Table 1 shows coconut meal has protein content of $19.3 \%$ and ME of 14 $\mathrm{MJ} / \mathrm{kg}$ whereas cassava meal has $2.5 \%$ protein and 14.6 $\mathrm{MJ} / \mathrm{kg} \mathrm{ME}$. Both ingredients are good source of energy. A high ME in cassava meal is due to its high starch content (Garcia \& Dale, 1999). In addition to high energy content, coconut meal is also a good source of protein as $70 \%$ of its protein is by-pass protein (Deville et al., 1980) which will contribute to a high milk yield (Nisa et al., 2008). Compared to these 2 supplements, palm oil solid waste only contains $12 \mathrm{MJ} / \mathrm{kg} \mathrm{ME}$, but it contains much higher protein $(12 \%$ vs $2.5 \%)$ than that cassava meal.

Tabel 1. Proximate analysis of cover crops, copra meal, milled cassava, and oilpalm solid waste

\begin{tabular}{lcccc}
\hline $\begin{array}{c}\text { Chemical } \\
\text { composition }\end{array}$ & $\begin{array}{c}\text { Cover } \\
\text { crops }^{* *}\end{array}$ & $\begin{array}{c}\text { Copra } \\
\text { meal }\end{array}$ & $\begin{array}{c}\text { Milled } \\
\text { cassava }\end{array}$ & $\begin{array}{c}\text { Palm oil } \\
\text { solid waste }\end{array}$ \\
\hline Dry matter (\%) & $15-20$ & 91.0 & 29.4 & 80.5 \\
Protein (\% DM) & $8-17$ & 19.2 & 2.5 & 12.0 \\
Crude fibre (\% DM) & $28-38$ & 28.0 & 8.2 & 30.0 \\
Fat (\% DM) & $1.5-2.3$ & 9.0 & 0.7 & 10.4 \\
ME (MJ/kg DM)* & $7-10$ & 14.0 & 14.6 & 12.0 \\
\hline
\end{tabular}

* $\mathrm{ME}=0.15 \mathrm{DCO} ;{ }^{* *}$ Taken from various references. 
Thus palm oil solid waste can be considered as medium type of feed supplement and can be used as ingredient in the concentrate diet. Moran (2009) recommended that a concentrate diet should have 11 to $12 \mathrm{MJ} / \mathrm{kg}$ dry matter of $\mathrm{ME}$ and $16 \%$ to $18 \%$ of crude protein.

\section{Milk Yield}

The addition of $1 \mathrm{~kg}$ palm oil solid waste in the diet of dairy buffalo increased milk yield by approximately $23.5 \%$ (10.5 L vs $8.5 \mathrm{~L})$. The increased milk yield was the result of increased metabolizable energy intake (MEI) of the cows which was estimated to be $5.2 \mathrm{MJ} / \mathrm{d}$ (see Table $2)$. The average of milk yield showed in Table 2 was measured during the first 2 months of lactation, the level of milk yield might be at peak. It is predicted that even after peak lactation, in which milk yield will decline, the cows given an additional of $1 \mathrm{~kg}$ palm oil solid waste will produce higher milk yield than the controls. It is estimated that in the first 2 months of lactation, the treatment diet will result in weight loss of $0.31 \mathrm{~kg} / \mathrm{d}$ while the control diet will result in weight gain of 0.07 $\mathrm{kg} / \mathrm{d}$ (Table 3). Generally, during the first 4-10 weeks of lactation, nutritional requirements is usually exceed voluntary intake, the amount of nutrient supplied by the feed is not enough to meet the nutrient requirements of the cows. To make up the nutrient deficit, body reserves namely fat, are mobilized and used for milk synthesis, therefore at this stage the cow will loose her body weight. However, 2-4 months after calving, cow dry matter consumption increase to a point where energy

Tabel 2. The estimated metabolizable energy intake (MEI), average milk yield, birth weight and live weight gain (LWG) of calves offered control and treatment diet

\begin{tabular}{lcc}
\hline \multicolumn{1}{c}{ Variables } & Control & Treatment \\
\hline MEI * (MJ) & 125.1 & 130.3 \\
Milk yield $(\mathrm{L} / \mathrm{d})$ & $8.5 \pm 0.75^{\mathrm{a}}$ & $10.5 \pm 0.61^{\mathrm{b}}$ \\
Birth weight $(\mathrm{kg})$ & $19.6 \pm 1.43^{\mathrm{a}}$ & $22.1 \pm 1.92^{\mathrm{b}}$ \\
LWG $(\mathrm{kg} / \mathrm{d})$ & $0.66 \pm 0.13^{\mathrm{a}}$ & $0.99 \pm 0.09^{\mathrm{b}}$ \\
\hline
\end{tabular}

* Dry matter intake $=0.025 \mathrm{LW}+0.1$ milk yield. $\mathrm{LW}=500 \mathrm{~kg}$

Means in the same row with different superscript differ significantly $(\mathrm{P}<0.05)$.

Tabel 3. The estimated metabolizable energy (ME) requirements of control and treated animal

\begin{tabular}{lcc}
\hline \multicolumn{1}{c}{ ME (MJ) } & Control & Treatment \\
\hline Maintenance & 54.0 & 54.0 \\
Production (Feed - Maint) & 71.1 & 76.3 \\
Milk production & 68.7 & 84.9 \\
Difference & 2.4 & -8.6 \\
Weght gain or loss (kg/d) & +0.07 & -0.31 \\
\hline
\end{tabular}

Milk ME $(\mathrm{MJ} / \mathrm{kg})=1.694(0.0386 \mathrm{BF}+0.0205 \mathrm{SNF}-0.236)$; buffalo milk $\mathrm{BF}=80 \mathrm{~g} / \mathrm{kg}$; buffalo milk $\mathrm{SNF}=94 \mathrm{~g} / \mathrm{kg}$.

ME for $1 \mathrm{~kg}$ weight gain=34 MJ.

$\mathrm{ME}$ for $1 \mathrm{~kg}$ weight loss= $28 \mathrm{MJ}$. input is greater than energy output resulting in positive energy balance for the reminder of lactation, at this stage cow will regain weight but milk yield will decline.

In this trial, it was estimated that there were more body reserve being used up than intake of energy in cows given palm oil solid waste as compared to the control. The higher loss of body reserve in cows fed palm oil solid waste was associated with presumably a higher body condition score at calving (Chagas et al., 2007; Bewley et al., 2008), this in turn resulted in a higher milk yield as indicated in Holstein-Friesian dairy cows (Berry et al., 2003; Berry et al., 2007; Roche et al., 2006 and 2007). In this experiment however, the values of weight loss and weight gain were only estimation, since body weight of the cows are not measured directly. Furthermore, the standard energy requirement for buffalo has not been made available, therefore all of the estimation here are based on the energy requirements for dairy cattle (MAFF, 1975).

Milk production of these buffalos may be further increased if higher inclusion of palm oil solid waste was given. The IGCARL (Indira Gandhi Center for Advanced Research on Livestock) claims that milk production of Murrah buffalo in India can reach up to $15 \mathrm{~L} / \mathrm{d}$. A cow with BW of $500 \mathrm{~kg}$, producing $15 \mathrm{~L} / \mathrm{d}$ of milk, approximately requires $175.3 \mathrm{MJ} / \mathrm{d}$ of $\mathrm{ME}$. This amount of energy can be met by feeding $6 \mathrm{~kg}$ of palm oil solid waste $+2 \mathrm{~kg}$ coconut meal $+2 \mathrm{~kg}$ cassava meal as a supplement. This ration will result in predicted cow weight loss of $0.43 \mathrm{~kg} / \mathrm{d}$ for the first 4-10 weeks of lactation. However, with the same ration, lesser weight loss is predicted if the cow has BW higher than $500 \mathrm{~kg}$ and producing 151 of milk per day (see Table 4 ).

Poor reproductive performance such as anoestrus and long calving interval in dairy buffaloes was reported by Qureshi et al. (2002). Supplementation of palm oil solid waste in the diet of lactating buffalo cows may also

Table 4. The estimated metabolizable energy (ME) requirements of cows with BW range from $500-600 \mathrm{~kg}$ and milk yield $15 \mathrm{~L} / \mathrm{d}$

\begin{tabular}{lccc}
\hline \multicolumn{1}{c}{ ME (MJ) } & $500 \mathrm{~kg}$ & $550 \mathrm{~kg}$ & $600 \mathrm{~kg}$ \\
\hline DM Intake (kg/d) & 14.0 & 15.25 & 16.5 \\
Feed in DM & & & \\
$\quad$ 6 kg palm oil solid waste & 72.0 & 72.0 & 72.0 \\
2 kg copra meal & 28.0 & 28.0 & 28.0 \\
2 kg cassava meal & 29.2 & 29.2 & 29.2 \\
$\quad$ Forage (8.5 MJ/kg DM) & 34.0 & 44.6 & 55.2 \\
$\quad$ Total Feed ME & 163.2 & 173.8 & 184.4 \\
Production: & & & \\
$\quad$ Maintenance & 54.0 & 59.0 & 63.0 \\
$\quad$ Milk production & 121.3 & 121.3 & 121.3 \\
$\quad$ Total Prod ME & 175.3 & 180.3 & 184.3 \\
Energy balance (Feed - Prod) & -12.1 & -6.2 & +0.1 \\
Weight loss/gain (kg/d) & -0.43 & -0.22 & +0.003 \\
\hline
\end{tabular}

$\mathrm{DM}=$ dry matter. $\mathrm{ME}$ for $1 \mathrm{~kg}$ buffalo milk is $8.09 \mathrm{MJ}$. 
speed up postpartum estrus, thus shorten the calving interval. This needs to be further investigated.

\section{Birth Weight and Calve Growth}

Table 2 shows calves birth weight from cows offered $1 \mathrm{~kg}$ palm oil solid waste were higher $(22.1 \mathrm{~kg}$ vs $19.6 \mathrm{~kg}$ ) than those from cows offered the control diet. The difference in calves birth weight was associated with improved $(5.2 \mathrm{MJ} / \mathrm{d})$ metabolizable energy intake of the dam. Calves born from the treated cows also had a better growth rate $(0.99 \mathrm{~kg} / \mathrm{d}$ vs $0.66 \mathrm{~kg} / \mathrm{d})$ than those born from the controls. The growth of calves before weaning is dependent upon 2 factors, the high quality of colostrums and feeding management to stimulate rumen growth (Moran 2005). These two factors may be responsible to the higher growth rate of the calves born from the treated cows. The treated cows might have a better quality of colostrums; since their calves were born with a higher BW, they consumed more colostrums than those with lower BW. All calves were always with their dam (both the treated and the control); those born from the treated cows might have access to palm oil solid waste and thus had a better LWG.

Delayed first calving age, longer calving interval, poor estrus expression in female buffaloes have been widely known (Drost, 2007). These conditions may be improved by better nutrition and management of heifers (Qureshi et al., 2002; Zicarelli et al., 2007) and male buffaloes (Sahoo et al., 2004; Wynn et al., 2009). Effect of inclusion of palm oil solid waste in the diet to increase MEI therefore should be studied to look at the effect on heifers as well as on male buffaloes. It is predicted that supplementation of palm oil solid waste may reduce slaughter age, so that the meat produced will have a better quality and better price. Furthermore, buffalo meat contains less fat and less cholesterol than beef (Khan \& Iqbal, 2009) for human health, buffalo meat is better than beef. Therefore it is expected that buffalo meat can be sold with a higher price.

\section{CONCLUSION}

The inclusion of palm oil solid waste in the diet of murrah buffalo significantly improved milk yield and calve growth rate. Based on its protein content and ME, palm oil solid waste is considered to be a medium type of supplement and can be included in the concentrate.

\section{REFERENCES}

AOAC. 1984. Official Method of Analysis. 14th Ed. Association of Official Analytical Chemist. Washington, D.C

Batubara, L. P. 2003. Potensi integrasi peternakan dengan perkebunan kelapa sawit sebagai simpul agribisnis ruminan. Wartazoa 13:83-91.

Berry, D. P., F. Buckley, P. Dalton, R. D. Evans, M. Rath, \& R. F.Veerkamp. 2003. Genetic relationships among body condition score, body weight, milk yield and fertility in dairy cows. J. Dairy Sci. 86:2193-2204.

Berry, D. P., F. Buckley, \& P. Dalton. 2007. Body condition score and live weight effects on milk production in Irish Holstein Friesian dairy cows. Animal 1:1351-1359.
Bewley, J. M., PAS, \& M. M. Schult. 2008. Review: An interdisciplinary review of body condition scoring in dairy cattle. The Professional Animal Scientist 24:507-529.

BPS. 2002. Statistik Indonesia 2000. Badan Pusat Statistik. Jakarta.

Chagas, L. M., J. J. Bass, D. Blache, C. R. Burke, J. K. Kay, D. R. Lindsay, M. C. Lucy, G. B. Martin, S. Meier, F. M. Rodes, W. W. Thacher, \& R. Webb. 2007. Invited review: New perspective on the role of nutrition and metabolic priorities in the subfertility of high producing dairy cows. J. Dairy Sci. 90: 4022-4032.

Chantalakkana, C. \& L. Falvey. 1999. Smallholder dairying in the tropics. ILRI, Nairobi, Kenya. 462 pp.

Deville, J., C. Morgan, \& S. Emmanuel. 1980. A comparison of the rumen degradability of some feeds by artificial-fibre bag technique. Trop. Anim. Prod. 5:1-3.

Drost, M. 2007. Bubaline versus bovine reproduction Theriogen. 68: 447-449

Garcia, M. \& N. Dale. 1999. Cassava root meal for poultry. J. Appl. Poult. Res. 8:132-137.

Khan, B. B. \& A. Iqbal. 2009. The water buffalo: An underutilized source of milk and meat: A Review. Pakistan J. Zoo. Supp. Ser. 9:517-521.

Kolver, E. S. 2003. Nutrition limitation to increase production from pasture -based system. Proceed. Nutr.Soc. 62: 291-300.

MAFF. 1975. Energy allowances and feeding systems for ruminants. Ministry of Agric.Fisheries and Food (HMSO), London.

Moran, J. B. 2005. Tropical Dairy Farming: Feeding Management for Small Holder Dairy Farmers in the Humid Tropics. Landlinks Press, Melbourne.

Moran, J. B. 2009. Key performance indicators to diagnose poor farm performance and profitability of smallholder dairy farmers in Asia. Asian-Aust.J.Anim.Sci. 22:1709-1717.

Nisa, M., A. Javaid, M. A. Shahzad, \& M. Sarwar. 2008 Influence of varying ruminally degradable to undegradable protein ratio on nutrient intake, milk yield, nitrogen balance, conception rate and days open in early lactating Nili-Ravi buffaloes (Bubalus bubalis). Asian Aust. J. Anim. Sci. 21:1303-1311.

Puppo, S., S. Bartocci, S. Terramocia, F. Grandoni, \& A. Amici. 2002. Rumen microbial accounts and in vivo digestibility in buffaloes and cattle given different diets. Anim.Sci. 75:323-329.

Pasaribu, T., A. P. Sinurat, T. Purwadaria, Supriyati, J. Rosida, \& H. Hamid. 1998. Peningkatan nilai gizi limpur sawit melalui proses fermentasi: Pengaruh jenis kapang, suhu, dan lama proses enzimatis. Jurnal Ilmu Ternak dan Veteriner 3:237-242.

Qureshi, M. S., H. Habib, H. A. Samad, M. M. Siddiqui, N. Ahmad, \& M. Syed. 2002. Reproduction-nutrition relationship in dairy buffaloes: Effect of intake of protein, energy and blood metabolites level. Asian-Austr.J.Anim. Sci. 15: 330-339.

Roche, J. R., D. P. Berry, \& E. S. Kolver. 2006. Holstein-Friesian strain and feed effects on milk production, body weight and body condition score profiles in grazing dairy cows. J. Dairy Sci. 89:3532.

Roche, J. R., J. M. Lee, K. A. Mcdonald, \& D. B. Berry. 2007. Relationships among body condition score, body weight and milk yield variables in pasture-based dairy cows. J.Dairy Sci .90:3802.

Sahoo, A., A. V. Elangovan, U. R. Mehra, \& U. B. Singh. 2004. Catalytic supplementation of urea-molases on nutritional performance of male buffalo (Bubalus bubalis) calves. Asian Aust. J. Anim. Sci. 17: 621-628.

Sarwar, M., M. A. Khan, M. Nisa, \& Z. Iqbal. 2002. Dairy industry in Pakistan: A scenario. Intl. J. Agric. Biol. 
3:420-428.

Terramoccia, S., S. Bartocci, A. Amici, \& F. Martilotti. 2000. Protein and protein-free dry matter rumen degradability in buffalo, cattle and sheep fed diets with different fiorage to concentrate ratio. Livest.Prod. Sci. 65: 185 - 195

Tilley, J. M. A. \& R. A. Terry. 1963. A two-stage technique for the in vitro digestion of forage crops. J. Brit. Grassland Soc. 18:104.

Utomo, B. N. \& E. Widjaja. 2004. Limbah padat pengolahan minyak sawit sebagai sumber nutrisi ternak ruminansia. Jurnal Libang Pertanian. 23:22-28.

Wanapat, M., A. Ngarmsang, S. Korkhuntot, N. Nantaso, C. Wachirapakorn, G. Beakes, \& P. Rowlinson. 2000. A comparative study on the microbial population of cattle and swamp buffalo raised under traditional village condition in northeast of Thailand. Asian Austr. J. Anim. Sci. 13:478-482.
Wanapat, M., N. Nantaso, C. Yuangklang, S. Wora-anu, A. Ngarmsang, C. Wachirapakorn, \& P. Rowlinson. 2003. Comparative study between swamp buffalo and native cattle in feed digestibility and potential transfer of buffalo rumen digesta into cattle. Asian Austr. J. Anim. Sci. $16: 473-534$.

Wynn, P. C., H. M. Warriach, A. Morgan, D. M. McGill, S. Hanif, M. Sarwar, A. Iqbal, P. A. Sheehy, \& R. D. Bush. 2009. Perinatal nutrition of the calf and its consequences for lifelong productivity. Asian. Aust. J. Anim. Sci. 22:756-764.

Zicarelli, F. C., C. Grassi, M. P. Gazaneo, I. Masiello, D. Vecchio, \& G. Campanile. 2007. Starter protein concentration and weaning of buffalo calf. Ital. J. Anim. Sci. 6 (Suppl.1): 515-517.

Yatno, N. Ramli, P. Harjosworo, A. Setiyono, \& T. Purwadaria. 2008. Sifat kimia dan nilai biologis konsentrat protein bungkil inti sawit hasil extraksi kombinasi fisik-kimia. Med. Pet. 31:178-185. 